\title{
Broad Neutralizing Antibodies to HIV Env and Other Complex Viral Antigens from Vaccinated Cows
}

Behnaz Heydarchi, Natalia A Salazar-Quiroz and Damian F J Purcell

Department of Microbiology and Immunology, The University of Melbourne at The Peter Doherty Institute for Infection \& Immunity, Melbourne, Australia

*Corresponding author: Damian F J Purcell, Department of Microbiology and Immunology, The University of Melbourne at The Peter Doherty Institute for Infection \& Immunity, Melbourne, Australia, Tel: 8344 6753; Fax: 9347 1540; E-mail: dfjp@unimelb.edu.au

Received date: November 01, 2016; Accepted date: November 29, 2016; Published date: December 02, 2016

Copyright: (c) 2016 Heydarchi B, et al. This is an open-access article distributed under the terms of the Creative Commons Attribution License, which permits unrestricted use, distribution, and reproduction in any medium, provided the original author and source are credited.

\begin{abstract}
The idea of using antibodies to restrain HIV viral replication has been a growing interest since many years ago. HIV-patient serum with elite virus-neutralizing breadth has led to the preparation of broadly neutralizing antibodies (BrNAbs) with long and highly mutated $\mathrm{CDRH} 3$ domains that can neutralize a broad array of viral strains and prevent transmission in animal models. Recent advances have resulted in the discovery of BrNAbs that are more potent and can neutralize many HIV-1 subtypes. However, elicitation of these antibodies in infected individuals usually requires a long time of antigen exposure. Though BrNAbs are shown to be successful either therapeutically or prophylactically against HIV-1, production of these antibodies in bulk, commercial-sized batches are expensive and non-affordable particularly for poor countries. Therefore, more durable preventative or therapeutic strategies are required. Immunization of the cows with HIV Env is shown to be capable of producing $20 \mathrm{~kg}$ purified anti-HIV-1 BrNAbs and this amount could be sufficient for 2 million $\times 10 \mathrm{mg}$ doses for formulation and pre-clinical testing as an HIV microbicide. In addition, bovine immunoglobulins typically have variable third heavy complementarity determining regions $(\mathrm{CDRH} 3)$ that may potentially facilitate access to antigenic epitopes that are very difficult for other species to engage. Thus, cows could be engaged to elicit anti-HIV antibodies with the features of human BrNAbs and bovine colostrum could be a promising and cheap resource for the development of combination microbicides.
\end{abstract}

Keywords: HIV Env; Immunoglobulins; BrNAbs

\section{Introduction}

A key component of a vaccine against human immunodeficiency infection (HIV) will be the production of BrNAbs capable of blocking infectivity of a diverse array of HIV strains. BrNAbs can emerge in some HIV-infected individuals after several years of infection [1]. The serum immunoglobulin $\mathrm{G}$ ( IgG) from these "elite neutralizer" patients can neutralize many different HIV-1 strains across various different subtypes [2]. While waiting for the development of a fully effective HIV vaccine capable of eliciting these BrNAbs that are considered essential for blocking HIV transmission, other prevention strategies have turned towards testing passive infusions of broadly HIVneutralizing monoclonal antibodies (BrNmAb) [3-6] derived from HIV-1 patients. These BrNmAbs have proven beneficial in long-acting therapeutic strategies, and they are now under evaluation as a systemic infusion with the BrNmAb to test their potential as a long-acting therapeutic $[7,8]$ and also for transmission prevention [9-11]. The Antibody Mediated Prevention (AMP) trial will be considered as an alternative or adjunct to pre-exposure prophylaxis (PrEP) with antiretroviral drug combinations, such as Truvada [12]. The PrEP regimens have already demonstrated robust prevention against HIV transmission in some human trials in men who have sex with men (MSM). Effective PrEP requires high adherence in MSM [13]. However, PrEP has significantly lower efficacy in women, and requires long-term adherent dosing before any protective efficacy is achieved [14].

In spite of three decades of intensive effort, no prophylactic HIV vaccine has demonstrated strong protection from virus transmission.
The most challenging factor towards finding a compelling vaccine is finding a way to stimulate strong BrNAbs for the wide array of circulating viral strains. To date, vaccination against HIV-1 in human and animal models have yielded no or just narrowly focussed neutralizing antibodies, respectively. However, recent immunization studies in llamas and cows have resulted in induction of BrNAbs. Induction of BrNAbs in these animals is highly informative, as the studies from past 2 decades revealed that the antibodies from these species have unique structure facilitating antibody-antigen interaction through the less accessible epitopes $[15,16]$. The cows, particularly, produce exceptionally long $\mathrm{CDRH} 3$ which could be potentially advantageous in vaccine research developments. But furthermore, antibodies from Cow and Llama have production properties that illuminate potentially cheaper alternative approaches for passive antibody-mediated prevention than the extremely expensive approach pursued using humanized mAbs in the AMP study.

\section{Bovine colostrum as viral therapeutics}

Immune modulation plays the most essential role in the recuperation of a patient from a life-threatening viral infection. An individual's immune system should act ideally to restrict and control the infection. The natural health benefit of bovine colostrum use has been known for centuries [17]. Bovine (cow and buffalo) IgG does not cross the placenta and IgG levels mount up in colostrum at levels 100fold to 1,000-fold larger than in human colostrum. New born calves must feed on colostrum for continuing health and viability. Even human children can use cow or buffalo colostrum to attain health benefits $[18,19]$. Bovine colostrum contains 3 major groups of 
components: nutritional components [20], immune factors [21] and growth factors [22].

The antiviral activity of colostrum is due to the presence of antibodies, lactoferrin, lactoperoxidase, lysozyme and other immune factors. These components control the pathogens by destroying their cell membranes or blocking the binding sites on the intestinal wall $[19,23]$. The cows can be vaccinated against a specific disease pathogen, which results in the production of antigen-specific antibodies and secretion in colostrum and milk. The immunization of the cow against a specific antigen may increase the specific antibody titer to 100-400 times in colostrum or milk, making a product known as hyperimmune colostrum. The total concentration of immunoglobulins in colostrum is $20-200 \mathrm{~g} / \mathrm{l}$ (average $60 \mathrm{~g} / \mathrm{l}$ ). Among all classes, IgG1 with almost $75 \%$ is the predominant class in colostral whey proteins followed by $\operatorname{IgM}$, IgA, and IgG2, respectively [24]. One promising application of bovine colostral and milk IgG is to provide passive immunity against diseases in other species, especially in humans. For instance, it has been suggested that consumption of immune milk from vaccinated cows is a potential means to control outbreaks of avian influenza, SARS, and other human respiratory diseases [25]. There are several studies evaluating passive immune protection via development and use of immune milk products [26-31].

Hyperimmune bovine colostrum is in particular helpful against human rotavirus [32]. Casein, a glycosylated protein, binds to the viral antigens directly using the glycosylated residue [33]. Vaccination of cows is a natural source of antibody production. However, the produced amount is not sufficient to cover the global requirement to reduce the number of death due to rotavirus-induced diarrhea [34]. Engineered Lactobacillus rhamnose GG with surface expressing the IgG-binding domains of protein G (GB1, GB2, and GB3) can bind to colostrums IgGs and enhance their potency in targeting rotavirus [34].

Furthermore, oral administration bovine colostrum to C57BL/6 mice improved immunity against influenza A virus (H1N1) through increasing natural killer cell cytotoxicity. One hypothesis is that colostrum components interact with innate receptors in the intestinal epithelium and stimulate these cells [35]. In another study, bovine colostrum IgG from a vaccinated cow with A/Puerto Rico/8/34 (PR8) influenza virus weakened the influenza symptoms in pre-treated $\mathrm{BALB} / \mathrm{c}$ mice [36].

\section{Anti- HIV/AIDS activity of bovine colostrum}

It was demonstrated that the infection-induced inflammation that occurs in the digestive tract of HIV-infected individuals can be reversed with bovine colostrum [37]. The bovine colostrum could possibly improve the tissue repair, mucosal integrity and also have direct antimicrobial actions [38]. Diarrhea is a common problem in AIDS patients, causing discomfort and malnutrition. Healthy people usually do not experience this complication. Human milk is effective in increasing circulating and tissue-resident helper $\mathrm{T}$ cells, consequently improving the immune system [39]. Bovine colostrum may be beneficial in HIV-infected individuals to re-establish the immune system and control the loss of $\mathrm{T}$ helper cells. It can also activate good health in the gastrointestinal immune system and promote mucosal integrity.

Elevated anti-HIV potency can be obtained from hyperimmune colostrum when bovine antibodies are directed against the HIV Envelope glycoproteins. Kramski et al. showed that polyclonal colostrum IgG fractions from cows hyperimmunized with HIV Env gp140 demonstrate potent and broad HIV neutralization. In these studies, cows were immunized with HIV envelope (Env) gp140 for very long 10-month duration, before and after conception. The results showed that the cows were capable of producing broad cross-subtype strain neutralizing activity that was transferred at high titer $\left(1: 1 \times 10^{6}\right)$ into colostrum. These antibodies include specificities that bind the highly conserved CD4bs on HIV Env trimmers and compete with the VRC01 mAb selected for analysis in the AMP trial and related BrNAbs, like b12 [40]. Heydarchi et al. showed that bovine antibodies from vaccinated cow, not only bind to CD4bs but also can neutralize HIV infectivity through this region [41]. In addition, they showed that vaccination of the cows with oligomeric AD8 gp140 could induce the antibody response against the SOS-IP gp140 Env, which is the antigen with the closest structure to the functional Env protein [41]. In another study, IgG from hyper immune bovine colostrum from Env gp140 trimer vaccinated cows showed anti-HIV Antibody-Dependent Cellular Cytotoxicity (ADCC) activity. Bovine IgG could bind to Fcyreceptors $\left(\mathrm{F}_{\mathrm{c}} \mathrm{Rs}\right)$ on human neutrophils, monocytes, and NK cells. Though anti-HIV-1 colostrum IgG displayed antibody-dependent killing, no killing was detected for non-immune colostrum IgG. ADDC activity was not seen with $F\left(a b^{\prime}\right)(2)$ fragments and was only dependent on $\mathrm{Fc}$ and $\mathrm{Fc} \gamma \mathrm{R}$ [42] (Figure 1). Antibodies supporting ADCC activity correlated with protection in the RV144 trial, the only human vaccine trial to date that demonstrates any protective efficacy [43].



Figure 1: Anti-HIV activity of colostrums from vaccinated cow. The purified IgG from colostrums of vaccinated cow showed ADCC and neutralization activity [40-42].

\section{Bovine CDRH3 length goes beyond expectation}

Potent antibody binding to key pathogen infectivity determinants requires a high level of evolution of the immunoglobulin CDRH3 domain to achieve high affinity for antigen [44]. The CDRH3 domain has the highest amino acid variability in IgG and plays the most critical role in the antigen binding interaction. This arises through two steps, first through a diversity generating mechanism using DNA rearrangement of variable $(\mathrm{V})$, diversity $(\mathrm{D})$ and joining $(\mathrm{J})$ genes to create CDRH3 with novel gene sequences $[45,46]$. In the second step, somatic hyper mutation (SHM) drives further maturation to higher affinity and this occurs in the presence of antigen in the germinal 
center of lymph nodes. In addition to VDJ recombination and SHM, the different use of $\mathrm{D}$ reading frames and variation in junction sites $(\mathrm{P}-$ nucleotides and addition of $\mathrm{N}$-nucleotides) contribute to $\mathrm{CDRH} 3$ diversity $[47,48]$. The ultimate result is an affinity maturation of the variable region, especially the $\mathrm{CDRH} 3$ domain, and this increases the IgG neutralizing activity against HIV Env antigen [49].

The human CDR H3 length is normally 8-16 amino acids which contribute to form a flat or undulating binding surface along with the other heavy and light CDRs. Broad HIV-strain neutralizing antibodies obtained from long-term infected patients frequently contain an unusually long protruding CDRH3 [50-55]. The average CDRH3 size in mouse is 3 amino acids shorter than those in human [56]. Rabbit antibodies, on the other hand, present a length distribution similar to humans, with a slightly shorter $\mathrm{CDRH} 3$ (up to 23 residues) but keeping the highest frequencies around 13 residues [57,58]. In mice and rabbit, there is a bias against long CDRH3 antibodies development [60,61] which causes difficulties in using small animals for HIV vaccination trials [60]. Camelids present $\mathrm{CDRH} 3$ regions of between 3 to 24 residues, with the highest frequency between 13 and 17 residues $[61,62]$. In addition to heterogenic antibodies, camelids also present homogenous, light-chain depleted antibodies [63]. These antibodies, called heavy chain antibodies, have a variable region called $\mathrm{VHH}$, which has its own CDR3 region. A comparison of VHH with conventional antibodies shows that the former group presents larger $\mathrm{CDH} 3$ length (between 7 and 24 residues) than the $\mathrm{VH}$ of conventional antibodies [61]. Heavy chain camelid antibodies offer the potential for high-level production in conventional bacterial and yeast biofermentation which may lead to large-scale, relatively low-cost production [64]. In contrast, the length of bovine CDRH3 is highly variable and longer (up to 70 amino acids) than those in other species particularly compared to human [16,65-68]. The antibodies with ultralong CDRH3 can comprise up to $10-15 \%$ of the entire bovine IgG repertoire (Figure 2) [16]. Crystal structure of the bovine antibodies with ultra-long $\mathrm{CDRH} 3$ shows that these long variable domains contribute to an unusual structure. These $\mathrm{CDRH} 3$ regions join to a particular set of lambda light chains with limited diversity [67].

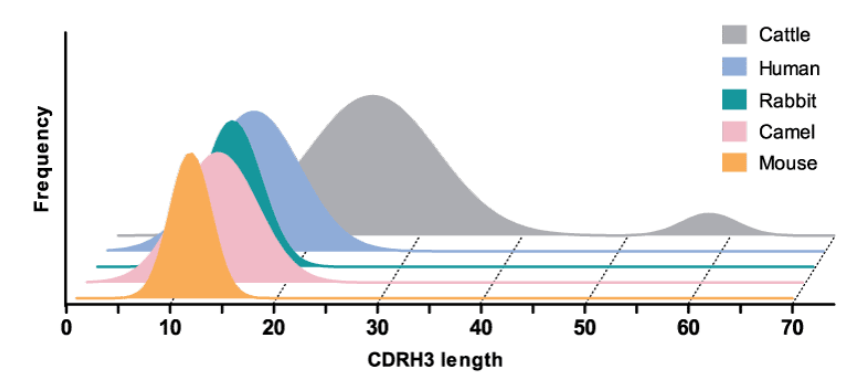

Figure 2: A comparison of $\mathrm{CDRH} 3$ length distribution between different species. The length of bovine CDRH3 is highly variable and longer (up to 70 amino acids) than those in other species particularly compared to human $[16,56,58,59,61,62]$.

In the naïve $\mathrm{B}$ cell pool, $3.5 \%$ of $\mathrm{B}$ cells have $\mathrm{CDRH} 3 \geq 24$ residues and $0.43 \%$ of them contain very long $\mathrm{CDRH} 3 \geq 28$ residues [69]. However, this percentage is substantial with consideration of the total potential number of 1012 different antibodies in the human B cell repertoire. This means that $\mathrm{B}$ cells with long $\mathrm{CDRH} 3$ can actively contribute in the human humoral immune system. It appears that $\mathrm{B}$ cells producing antibodies with long CDRH3 are selected with HIV-1 Env to generate BrNAbs targeting deep epitopes of HIV-1 Env. Furthermore, there is a meaningful relationship between long CDR H3 (20-34 residues) and BrNAbs especially in antibodies targeting the glycan-related V1/V2 and V3 category, the gp120/gp41 bridging region category and the gp41-MPER category. This contrasts with the average 16 residues of CDRH3 in the antibodies elicited by other viral antigens [54,70]. The role of such long CDRH3 (18 residues) in b12, as a member of CD4 binding site antibodies, is to access a glycosylation site $[71,72]$. However, the CDRH3 in CD4bs BrNAbs are shorter than the glycan-related V1/V2 and V3 category. The longest CDRH3 belongs to PG9-like and PGT128-like BrNAbs that forms a sub-domain that is important for neutralization (Figure 3). These $\mathrm{CDRH} 3$ regions help the antibodies to penetrate the glycan shield of Env trimer then interact with the V1/V2 and/or V3 region of gp120 [73]. Also, CDRH3 is an important component in gp41-reactive antibodies such as $2 \mathrm{~F} 5$ (CDRH3 of 22 residues) and 4E10 (CDRH3 of 18 residues) which performs the additional activity causing a hydrophobic interaction with the membrane [74-80] and forming a loop to contact the highly conserved hydrophobic residues on gp41 [52,81-83].

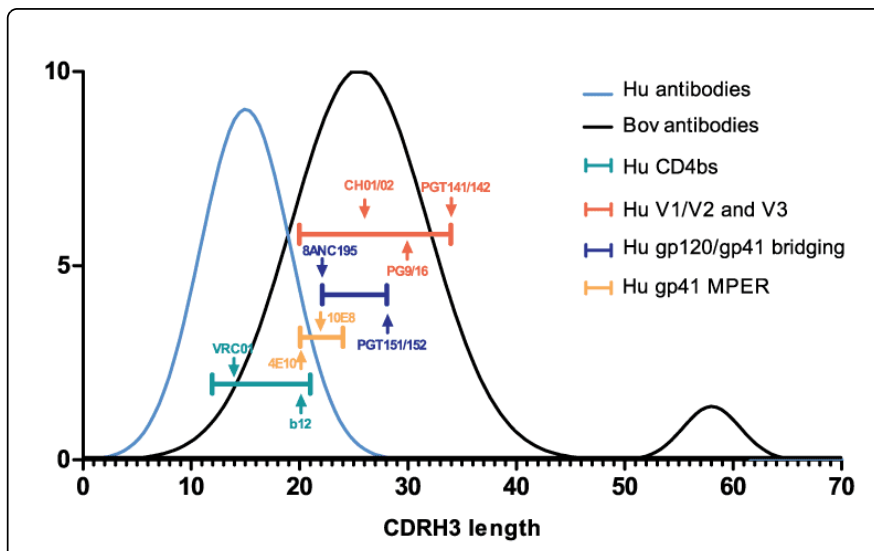

Figure 3: Comparison of bovine $\mathrm{CDRH} 3$ length with the $\mathrm{CDRH} 3$ size of human BrNAbs. The bovine CDRH3 covers the size of CDRH3 in all human BrNAbs. Bov: bovine; Hu: Human antibodies $[16,50-55]$.

\section{Aromatic residues in bovine $\mathrm{CDRH} 3$ pave the wave toward HIV neutralization}

Previous studies on human immunoglobulins derived from HIV patients illustrate that although the presence of Cys and aromatic residues is a rare feature, these amino acids play a crucial role for HIV BrNAbs in epitope binding or virus neutralization. The substitution of aromatic residues, mainly Trp or tyrosine (Tyr), in MPER binding antibodies reduces the neutralization activity of these antibodies $[74,84]$. Also, the importance of Cys and aromatic residues such as Trp is shown in neutralization activity of CD4bs BrNAbs antibodies [85,86], highlighting the significant function of these residues in either directly in the antigen binding interaction or involvement in shaping the required structure for epitope binding.

The activity of patient-derived HIV-1 BrNAbs requires an extensive affinity maturation in the lymph node germinal centers in comparison with other human IgG antibodies against most other pathogens, or with poorly neutralizing HIV antibodies [70,87,88]. The most 
important of the maturation mechanisms is SHM particularly in the heavy variable region [89-95]. A high degree of amino acid SHMs ranging from $9.4 \%$ for M66.6 (gp41 MPER antibody) up to $47.9 \%$ for VRC06 (CD4bs antibody) is a characteristic feature of HIV-1 BrNAbs [96]. The importance of SHM is demonstrated by low or absent reactivity of predicted un-mutated germline ancestors of BrNAbs $[97,98]$.

In Bos taurus, the $V$ gene is almost limited to one family (gl.110.20) $[65,66,68]$. However, the bovine immune system has a robust function which implies that some diversification mechanisms are employed to help the immunoglobulins to target epitopes of diverse pathogens. High level SHM in the immunoglobulins is one of the main strategies that bovine immune system uses to provide enough antibody evolution and adaption for efficient antigen recognition [99]. There are other major factors that result in the bovine immunoglobulins being exceptional amongst immunoglobulins derived from other species. Most unique is that bovine IgG can have ultra-long CDRH3 that form a $\beta$ strand "stalk" that supports a structurally classified, disulfidebonded "knob" domain. To create diverse antigen binding surfaces, a Cys diversification is employed through a single $\mathrm{V}(\mathrm{D}) \mathrm{J}$ event in cows which reshape the knob domain in the ultra-long CDRH3 regions [16]. In bovine, $\mathrm{CDRH} 3$ domains are particularly elongated, and Cys residues are normally frequent forming structures that involve disulfide bonds [67]. The DH2 germline gene encodes repeating motif of Gly-Tyr-Gly which could be mutated into cysteine $[16,66]$. In another study, the critical contribution of aromatic residues (particularly Trp and His) for HIV Env binding has been revealed (Heydarchi et al. submitted). The long CDRH3, high level of SHMs and presence of Cys and aromatic residues are parts of the normal bovine immunoglobulin that are comparable to what was observed from human neutralizing immunoglobulins which in contrast, require a long time to develop and are not observed in normal antibodies [1].

\section{Limitation and Challenges}

There are some challenges with the production of virus-specific bovine antibodies from colostrum. Our experience with HIV Env antibodies suggests potent neutralizing IgG antibodies required a relatively long maturation time when produced by pregnant cows [40]. Furthermore, the large body mass of the cows may require much more vaccine compared to other animals [40,100-102]. Additionally, highest concentrations of colostrum antibody are found in the first colostrum and this must be collected immediately after the unpredictable event of calving. Nevertheless, production of large scale anti-viral components and antibodies compensates for this drawback.

Other potential issues may arise when animal-derived un-purified polyclonal antibodies from colostrum are used for clinical applications and these materials would usually require purification of IgGs [103]. In general, quantitative and qualitative batch-to-batch variation is the another potential obstacle with the use of polyclonal antibodies from animals [104]. Though passive immunization with the bovine polyclonal antibodies can prevent or control infection [26-31,40], a general problem for polyclonal antibodies is that a large portion of stimulated antibodies will target non-neutralizing epitopes and titer of specific antibodies may be low [42]. However, one strategy to cope this problem may be the production of the monoclonal BrNAbs targeting conserved epitopes among different subtypes of a virus. Finally humanization of the bovine monoclonal antibodies will be required to modify the protein sequence towards antibodies naturally tolerated in humans $[104,106]$ therefore reducing anti-antibody responses [107].
On the whole, though there are some challenges existing with the use of bovine polyclonal antibodies from colostrum, it seems that the advantages of repertoire diversity and production scale outweigh the disadvantages when bovine-derived antibodies are employed in the control and/or treatment of antigenically complex viruses, such as HIV.

\section{Conclusion}

The colostrum-derived IgG could improve the immunity against different viruses including HIV. It is curious that bovine yields remarkable high titers of BrNAbs after vaccination but that this does not occur following vaccination of other species. Vaccinations with HIV Env gp140 trimmers that have evolved to evade human antibody immunity may present epitopes in bovine that are anergic in primates [108]. Furthermore, as previously shown the pre-existing immunity against human microbiota could mislead the immune system to induce non-neutralizing antibodies [109]. So, it is also possible that the microbiota that shapes the polyfunctional B cell precursors that spawn BrNAbs in humans are different to those in a ruminant, like the bovine, leading to a more rapid and reproducible production of neutralizing antibodies. Finally, the unprecedented long length of the CDRH3 regions of the bovine IgG $[65,66]$ leads to V-regions that make long $\mathrm{CDRH} 3$ with an average $\mathrm{CDRH} 3$ length that is equal to the maximum size for human $\mathrm{CDRH} 3$ frequently observed in BrNAb from human [54,71]. In addition, high a rate of SHM is used in the bovine antibodies [109] may lead to elicit BrNAbs with characteristic highly mutated. Indeed, the bovine antibodies from vaccinated cows could eventually benefit HIV-infected individuals by means of their extraordinary features.

\section{References}

1. Sather DN, Armann J, Ching LK, Mavrantoni A, Sellhorn G, et al. (2009) Factors associated with the development of cross-reactive neutralizing antibodies during human immunodeficiency virus type 1 infection. J Virol 83: 757-769.

2. Bunnik EM, Euler Z, Welkers MR, Boeser-Nunnink BD, Grijsen ML, et al. (2010) Adaptation of HIV-1 envelope gp120 to humoral immunity at a population level. Nat Med 16: 995-997.

3. Klein F, Mouquet H, Dosenovic P, Scheid JF, Scharf L, et al. (2013) Antibodies in HIV-1 vaccine development and therapy. Science 341: 1199-1204.

4. Watkins JD, Siddappa NB, Lakhashe SK, Humbert M, Sholukh A, et al. (2011) An anti-HIV-1 V3 loop antibody fully protects cross-clade and elicits T-cell immunity in macaques mucosally challenged with an R5 clade C SHIV. PLoS One 6: e18207.

5. Mascola JR, Montefiori DC (2010) The role of antibodies in HIV vaccines. Annu Rev Immunol 28: 413-444.

6. Kramer VG, Siddappa NB, Ruprecht RM (2007) Passive immunization as tool to identify protective HIV-1 Env epitopes. Curr HIV Res 5: 642-655.

7. Barouch DH, Whitney JB, Moldt B, Klein F, Oliveira TY, et al. (2013) Therapeutic efficacy of potent neutralizing HIV-1-specific monoclonal antibodies in SHIV-infected rhesus monkeys. Nature 503: 224-228.

8. Fouts TR, Bagley K, Prado IJ, Bobb KL, Schwartz JA, et al. (2015) Balance of cellular and humoral immunity determines the level of protection by HIV vaccines in rhesus macaque models of HIV infection. Proc Natl Acad Sci U S A 112: E992-999.

9. Duncan CJ, Williams JP, Schiffner T, Gärtner K, Ochsenbauer C, et al. (2014) High-multiplicity HIV-1 infection and neutralizing antibody evasion mediated by the macrophage-T cell virological synapse. J Virol 88: 2025-2034.

10. Gupta S, Gach JS, Becerra JC, Phan TB, Pudney J, et al. (2013) The Neonatal Fc receptor (FcRn) enhances human immunodeficiency virus 
type 1 (HIV-1) transcytosis across epithelial cells. PLoS Pathog 9: e1003776.

11. Horwitz JA, Halper-Stromberg A, Mouquet H, Gitlin AD, Tretiakova A, et al. (2013) HIV-1 suppression and durable control by combining single broadly neutralizing antibodies and antiretroviral drugs in humanized mice. Proc Natl Acad Sci U S A 110: 16538-16543.

12. Siskind RL, Andrasik M, Karuna ST, Broder GB, Collins C, et al. (2016) Engaging Transgender People in NIH-Funded HIV/AIDS Clinical Trials Research. J Acquir Immune Defic Syndr 72: S243-247.

13. Celum C, Baeten JM (2012) Tenofovir-based pre-exposure prophylaxis for HIV prevention: evolving evidence. Curr Opin Infect Dis 25: 51-57.

14. Marrazzo JM, Ramjee G, Richardson BA, Gomez K, Mgodi N, et al. (2015) Tenofovir-based preexposure prophylaxis for HIV infection among African women. N Engl J Med 372: 509-518.

15. De Genst E, Saerens D, Muyldermans S, Conrath K (2006) Antibody repertoire development in camelids. Dev Comp Immunol 30: 187-198.

16. Wang F, Ekiert DC, Ahmad I, Yu W, Zhang Y, et al. (2013) Reshaping antibody diversity. Cell 153: 1379-1393.

17. Hurley WL, Theil PK (2011) Perspectives on immunoglobulins in colostrum and milk. Nutrients 3: 442-474.

18. Elfstrand L, Lindmark-Månsson H, Paulsson M, Nyberg LBÅ (2002) Immunoglobulins, growth factors and growth hormone in bovine colostrum and the effects of processing. Int Dairy J 12:879-87.

19. van Hooijdonk AC, Kussendrager KD, Steijns JM (2000) In vivo antimicrobial and antiviral activity of components in bovine milk and colostrum involved in non-specific defence. Br J Nutr 84 Suppl 1: S127-134.

20. MACY IG (1949) Composition of human colostrum and milk. Am J Dis Child 78: 589-603.

21. Ogra SS, Ogra PL (1987) Immunological aspects of human colostrum and milk. Journal of Pediatrics 92: 550-555.

22. Pakkanen RJA (1997) Growth factors and antimicrobial factors in bovine colostrum. Int Dairy J 7: 285-297.

23. Ellison RT, Giehl TJ (1991) Killing of gram-negative bacteria by lactoferrin and lysozyme. J Clin Invest 88: 1080-1091.

24. Marnila P, Korhonen H, Roginski, Fuquay HJW, Fox PF (2002) Colostrum. In: Encyclopedia of Dairy Sciences, (Edn.) Academic Press, London.

25. Alisky J (2009) Bovine and human-derived passive immunization could help slow a future avian influenza pandemic. Med Hypotheses 72: 74-75.

26. Struff WG, Sprotte G (2008) Bovine colostrum as a biologic in clinical medicine: a review--Part II: clinical studies. Int J Clin Pharmacol Ther 46: 211-225.

27. Struff WG, Sprotte G (2007) Bovine colostrum as a biologic in clinical medicine: a review. Part I: biotechnological standards, pharmacodynamic and pharmacokinetic characteristics and principles of treatment. Int J Clin Pharmacol Ther 45: 193-202.

28. Zinkernagel RM (2001) Maternal antibodies, childhood infections, and autoimmune diseases. N Engl J Med 345: 1331-1335.

29. Korhonen H, Marnila P, Gill HS (2000) Bovine milk antibodies for health. Br J Nutr 84 Suppl 1: S135-146.

30. Zeitlin L, Cone RA, Moench TR, Whaley KJ (2000) Preventing infectious disease with passive immunization. Microbes Infect 2: 701-708.

31. Weiner C, Pan Q, Hurtig M, Borén T, Bostwick E, et al. (1999) Passive immunity against human pathogens using bovine antibodies. Clin Exp Immunol 116: 193-205.

32. Mestecky J, Russell MW (1998) Passive and active protection against disorders of the gut. Vet Q 20: 83-87.

33. Davidson GP, Whyte PB, Daniels E, Franklin K, Nunan H, et al. (1989) Passive immunisation of children with bovine colostrum containing antibodies to human rotavirus. Lancet 2: 709-712.

34. Mitra AK, Mahalanabis D, Ashraf H, Unicomb L, Eeckels R, et al. (1995) Hyperimmune cow colostrum reduces Diarrhea due to rotavirus: a double-blind, controlled clinical trial. Acta Paediatr 84: 996-1001.
35. Gunaydin G, Zhang R, Hammarstrom L, Marcotte H (2014) Engineered Lactobacillus rhamnosus GG expressing IgG-binding domains of protein G: Capture of hyperimmune bovine colostrum antibodies and protection against diarrhea in a mouse pup rotavirus infection model. Vaccine 32: 470-477.

36. Wong EB, Mallet JF, Duarte J, Matar C, Ritz BW (2014) Bovine colostrum enhances natural killer cell activity and immune response in a mouse model of influenza infection and mediates intestinal immunity through toll-like receptors 2 and 4. Nutr Res 34: 318-325.

37. Ng WC, Wong V, Muller B, Rawlin G, Brown LE (2010) Prevention and treatment of influenza with hyperimmune bovine colostrum antibody. PLoS One 5: e13622.

38. Zoltan PR (1998) Bovine colostrum emerges as immunity modulator. Am J Nat Med 5: 19-23.

39. Rathe M, Müller K, Sangild PT, Husby S (2014) Clinical applications of bovine colostrum therapy: a systematic review. Nutr Rev 72: 237-254.

40. Wirt DP, Adkins LT, Palkowetz KH, Schmalstieg FC, Goldman AS (1992) Activated and memory $\mathrm{T}$ lymphocytes in human milk. Cytometry 13: 282-290.

41. Kramski M, Center RJ, Wheatley AK, Jacobson JC, Alexander MR, et al. (2012) Hyperimmune bovine colostrum as a low-cost, large-scale source of antibodies with broad neutralizing activity for HIV-1 envelope with potential use in microbicides. Antimicrob Agents Chemother 56: 4310-4319.

42. Heydarchi B, Center RJ, Gonelli C, Muller B, Mackenzie C, et al. (2016) Repeated Vaccination of Cows with HIV Env gp140 during Subsequent Pregnancies Elicits and Sustains an Enduring Strong Env-Binding and Neutralising Antibody Response. PLoS One 11: e0157353.

43. Kramski M, Lichtfuss GF, Navis M, Isitman G, Wren L, et al. (2012) AntiHIV-1 antibody-dependent cellular cytotoxicity mediated by hyperimmune bovine colostrum IgG. Eur J Immunol 42: 2771-2781.

44. Tomaras GD, Ferrari G, Shen X, Alam SM, Liao HX, et al. (2013) Vaccine-induced plasma IgA specific for the C1 region of the HIV-1 envelope blocks binding and effector function of IgG. Proc Natl Acad Sci U S A 110: 9019-9024.

45. Ohno S, Mori N, Matsunaga T (1985) Antigen-binding specificities of antibodies are primarily determined by seven residues of VH. Proc Natl Acad Sci U S A 82: 2945-2949.

46. Fugmann SD, Lee AI, Shockett PE, Villey IJ, Schatz DG (2000) The RAG proteins and $\mathrm{V}(\mathrm{D}) \mathrm{J}$ recombination: complexes, ends, and transposition. Annu Rev Immunol 18: 495-527.

47. Smider V, Chu G (1997) The end-joining reaction in $V(D) J$ recombination. Semin Immunol 9: 189-197.

48. Bassing CH, Swat W, Alt FW (2002) The mechanism and regulation of chromosomal V(D)J recombination. Cell 109: S45-55.

49. Tonegawa S (1983) Somatic generation of antibody diversity. Nature 302: 575-581.

50. Di Noia JM, Neuberger MS (2007) Molecular mechanisms of antibody somatic hypermutation. Annu Rev Biochem 76: 1-22.

51. Ekiert DC, Kashyap AK, Steel J, Rubrum A, Bhabha G, et al. (2012) Cross-neutralization of influenza A viruses mediated by a single antibody loop. Nature 489: 526-532.

52. McLellan JS, Pancera M, Carrico C, Gorman J, Julien JP, et al. (2011) Structure of HIV-1 gp120 V1/V2 domain with broadly neutralizing antibody PG9. Nature 480: 336-343.

53. Pejchal R, Walker LM, Stanfield RL, Phogat SK, Koff WC, et al. (2010) Structure and function of broadly reactive antibody PG16 reveal an H3 subdomain that mediates potent neutralization of HIV-1. Proc Natl Acad Sci USA 107: 11483-11488.

54. Kwong PD, Wilson IA (2009) HIV-1 and influenza antibodies: seeing antigens in new ways. Nat Immunol 10: 573-578.

55. Collis AV, Brouwer AP, Martin AC (2003) Analysis of the antigen combining site: correlations between length and sequence composition of the hypervariable loops and the nature of the antigen. J Mol Biol 325:337-54. 
56. Saphire EO, Parren PW, Pantophlet R, Zwick MB, Morris GM, et al. (2001) Crystal structure of a neutralizing human IGG against HIV-1: a template for vaccine design. Science 293: 1155-1159.

57. Shi B, Ma L, He X, Wang X, Wang P, et al. (2014) Comparative analysis of human and mouse immunoglobulin variable heavy regions from IMGT/ LIGM-DB with IMGT/HighV-QUEST. Theor Biol Med Model 11:30.

58. Lavinder JJ, Hoi KH, Reddy ST, Wine Y, Georgiou G (2014) Systematic characterization and comparative analysis of the rabbit immunoglobulin repertoire. PLoS One 9: e101322.

59. Wu TT, Johnson G, Kabat EA (1993) Length distribution of CDRH3 in antibodies. Proteins 16: 1-7.

60. Zemlin M, Klinger M, Link J, Zemlin C, Bauer K, et al. (2003) Expressed murine and human CDR-H3 intervals of equal length exhibit distinct repertoires that differ in their amino acid composition and predicted range of structures. J Mol Biol 334:733-749.

61. Ivanov II, Schelonka RL, Zhuang Y, Gartland GL, Zemlin M, et al. (2005) Development of the expressed Ig CDR-H3 repertoire is marked by focusing of constraints in length, amino acid use, and charge that are first established in early B cell progenitors. J Immunol 174: 7773-7780.

62. Griffin LM, Snowden JR, Lawson AD, Wernery U, Kinne J, et al. (2014) Analysis of heavy and light chain sequences of conventional camelid antibodies from Camelus dromedarius and Camelus bactrianus species. J Immunol Methods 405: 35-46.

63. Vu KB, Ghahroudi MA, Wyns L, Muyldermans S (1997) Comparison of llama VH sequences from conventional and heavy chain antibodies. Mol Immunol 34: 1121-1131.

64. Hamers-Casterman C, Atarhouch T, Muyldermans S, Robinson G, Hamers C, et al. (1993) Naturally occurring antibodies devoid of light chains. Nature 363: 446-448.

65. Gorlani A, Brouwers J, McConville C, van der Bijl P, Malcolm K, et al. (2012) Llama antibody fragments have good potential for application as HIV type 1 topical microbicides. AIDS Res Hum Retroviruses 28: 198-205.

66. Zhao Y, Jackson SM, Aitken R (2006) The bovine antibody repertoire. Dev Comp Immunol 30: 175-186.

67. Sinclair MC, Gilchrist J, Aitken R (1997) Bovine IgG repertoire is dominated by a single diversified VH gene family. J Immunol 159: 3883-3889.

68. Saini SS, Allore B, Jacobs RM, Kaushik A (1999) Exceptionally long CDR3H region with multiple cysteine residues in functional bovine IgM antibodies. Eur J Immunol 29: 2420-2426.

69. Lopez O, Perez C, Wylie D (1998) A single VH family and long CDR3s are the targets for hypermutation in bovine immunoglobulin heavy chains. Immunol Rev 162: 55-66.

70. Briney BS, Willis JR, Crowe JJE (2012) Human peripheral blood antibodies with long HCDR3s are established primarily at original recombination using a limited subset of germline genes. PLoS One 7: e36750.

71. Tiller T, Tsuiji M, Yurasov S, Velinzon K, Nussenzweig MC, et al. (2007) Autoreactivity in human IgG+ memory B cells. Immunity 26: 205-213.

72. Zhou T, Xu L, Dey B, Hessell AJ, Van Ryk D, et al. (2007) Structural definition of a conserved neutralization epitope on HIV-1 gp120. Nature 445: 732-737.

73. Burton DR, Pyati J, Koduri R, Sharp SJ, Thornton GB, et al. (1994) Efficient neutralization of primary isolates of HIV-1 by a recombinant human monoclonal antibody. Science 266: 1024-1027.

74. Pancera M, McLellan JS, Wu X, Zhu J, Changela A, et al. (2010) Crystal structure of PG16 and chimeric dissection with somatically related PG9: structure-function analysis of two quaternary-specific antibodies that effectively neutralize HIV-1. J Virol 84: 8098-8110.

75. Scherer EM, Leaman DP, Zwick MB, McMichael AJ, Burton DR (2010) Aromatic residues at the edge of the antibody combining site facilitate viral glycoprotein recognition through membrane interactions. Proc Natl Acad Sci U S A 107: 1529-1534.
76. Ofek G, McKee K, Yang Y, Yang ZY, Skinner J, et al. (2010) Relationship between antibody 2F5 neutralization of HIV-1 and hydrophobicity of its heavy chain third complementarity-determining region. J Virol 84: 2955-2962.

77. Alam SM, Morelli M, Dennison SM, Liao HX, Zhang R, et al. (2009) Role of HIV membrane in neutralization by two broadly neutralizing antibodies. Proc Natl Acad Sci U S A 106: 20234-20239.

78. Julien JP, Huarte N, Maeso R, Taneva SG, Cunningham A, et al. (2010) Ablation of the complementarity-determining region $\mathrm{H} 3$ apex of the antiHIV-1 broadly neutralizing antibody $2 \mathrm{~F} 5$ abrogates neutralizing capacity without affecting core epitope binding. J Virol 84: 4136-4147.

79. Ofek G, Tang M, Sambor A, Katinger H, Mascola JR, et al. (2004) Structure and mechanistic analysis of the anti-human immunodeficiency virus type 1 antibody $2 \mathrm{~F} 5$ in complex with its gp41 epitope. J Virol 78: 10724-10737.

80. Buchacher A, Predl R, Strutzenberger K, Steinfellner W, Trkola A, et al. (1994) Generation of human monoclonal antibodies against HIV-1 proteins; electrofusion and Epstein-Barr virus transformation for peripheral blood lymphocyte immortalization. AIDS Res Hum Retroviruses 10: 359-369.

81. Purtscher M, Trkola A, Gruber G, Buchacher A, Predl R, et al. (1994) A broadly neutralizing human monoclonal antibody against gp41 of human immunodeficiency virus type 1. AIDS Res Hum Retroviruses 10: 1651-1658.

82. Kong L, Lee JH, Doores KJ, Murin CD, Julien JP, et al. (2013) Supersite of immune vulnerability on the glycosylated face of HIV-1 envelope glycoprotein gp120. Nat Struct Mol Biol 20: 796-803.

83. Kwong PD, Mascola JR (2012) Human antibodies that neutralize HIV-1: identification, structures, and B cell ontogenies. Immunity 37: 412-425.

84. Mouquet H, Scharf L, Euler Z, Liu Y, Eden C, et al. (2012) Complex-type $\mathrm{N}$-glycan recognition by potent broadly neutralizing HIV antibodies. Proc Natl Acad Sci U S A 109: E3268-3277.

85. Ofek G, Zirkle B, Yang Y, Zhu Z, McKee K, et al. (2014) Structural basis for HIV-1 neutralization by 2 F5-like antibodies $\mathrm{m} 66$ and m66.6. J Virol 88: 2426-2441.

86. West JAP, Diskin R, Nussenzweig MC, Bjorkman PJ (2012) Structural basis for germ-line gene usage of a potent class of antibodies targeting the CD4-binding site of HIV-1 gp120. Proc Natl Acad Sci U S A 109: E2083-2090.

87. Doria-Rose NA, Schramm CA, Gorman J, Moore PL, Bhiman JN, et al. (2014) Developmental pathway for potent V1V2-directed HIVneutralizing antibodies. Nature 509: 55-62.

88. Wrammert J, Koutsonanos D, Li GM, Edupuganti S, Sui J, et al. (2011) Broadly cross-reactive antibodies dominate the human B cell response against 2009 pandemic H1N1 influenza virus infection. J Exp Med 208: 181-193.

89. Scheid JF, Mouquet H, Feldhahn N, Seaman MS, Velinzon K, et al. (2009) Broad diversity of neutralizing antibodies isolated from memory B cells in HIV-infected individuals. Nature 458: 636-640.

90. Liao HX, Lynch R, Zhou T, Gao F, Alam SM, et al. (2013) Co-evolution of a broadly neutralizing HIV-1 antibody and founder virus. Nature 496 : 469-476.

91. Bonsignori M, Hwang KK, Chen X, Tsao CY, Morris L, et al. (2011) Analysis of a clonal lineage of HIV-1 envelope V2/V3 conformational epitope-specific broadly neutralizing antibodies and their inferred unmutated common ancestors. J Virol 85: 9998-10009.

92. Scheid JF, Mouquet H, Ueberheide B, Diskin R, Klein F, et al. (2011) Sequence and structural convergence of broad and potent HIV antibodies that mimic CD4 binding. Science 333: 1633-1637.

93. Walker LM, Phogat SK, Chan-Hui PY, Wagner D, Phung P, et al. (2009) Broad and potent neutralizing antibodies from an African donor reveal a new HIV-1 vaccine target. Science 326: 285-289.

94. Wu X, Zhou T, Zhu J, Zhang B, Georgiev I, et al. (2011) Focused evolution of HIV-1 neutralizing antibodies revealed by structures and deep sequencing. Science 333: 1593-602. 
Citation: Heydarchi B, Quiroz NAS, Purcell DFJ (2016) Broad Neutralizing Antibodies to HIV Env and Other Complex Viral Antigens from Vaccinated Cows. J Vaccines Vaccin 7: 347. doi:10.4172/2157-7560.1000347

Page 7 of 7

95. Corti D, Langedijk JP, Hinz A, Seaman MS, Vanzetta F, et al. (2010) Analysis of memory B cell responses and isolation of novel monoclonal antibodies with neutralizing breadth from HIV-1-infected individuals. PLoS One 5: e8805.

96. Wu X, Yang ZY, Li Y, Hogerkorp CM, Schief WR, et al. (2010) Rational design of envelope identifies broadly neutralizing human monoclonal antibodies to HIV-1. Science 329: 856-861

97. Yu L, Guan Y (2014) Immunologic Basis for Long HCDR3s in Broadly Neutralizing Antibodies Against HIV-1. Front Immunol 5: 250.

98. Prabakaran P, Zhu Z, Chen W, Gong R, Feng Y, et al. (2012) Origin, diversity, and maturation of human antiviral antibodies analyzed by highthroughput sequencing. Front Microbiol 3: 277.

99. Mouquet H, Scheid JF, Zoller MJ, Krogsgaard M, Ott RG, et al. (2010) Polyreactivity increases the apparent affinity of anti-HIV antibodies by heteroligation. Nature 467: 591-595.

100. Kaushik AK, Kehrli JME, Kurtz A, Ng S, Koti M, et al. (2009) Somatic hypermutations and isotype restricted exceptionally long $\mathrm{CDR} 3 \mathrm{H}$ contribute to antibody diversification in cattle. Vet Immunol Immunopathol 127: 106-113.

101. Nkolola JP, Peng HQ, Settembre EC, Freeman M, Grandpre LE, et al. (2010) Breadth of Neutralizing Antibodies Elicited by Stable, Homogeneous Clade A and Clade C HIV-1 gp140 Envelope Trimers in Guinea Pigs. Journal of Virology 84: 3270-3279.
102. Center RJ, Wheatley AK, Campbell SM, Gaeguta AJ, Peut V, et al. (2009) Induction of HIV-1 subtype $\mathrm{B}$ and AE-specific neutralizing antibodies in mice and macaques with DNA prime and recombinant gp140 protein boost regimens. Vaccine 27: 6605-6612.

103. Kang YK, Andjelic S, Binley JM, Crooks ET, Franti M, et al. (2009) Structural and immunogenicity studies of a cleaved, stabilized envelope trimer derived from subtype A HIV-1. Vaccine 27: 5120-5132.

104. Pichler WJ (2008) Drug hypersensitivity. St Louis, Mo: Mosby/Elsevier.

105. Lipman NS, Jackson LR, Trudel LJ, Weis-Garcia F (2005) Monoclonal versus polyclonal antibodies: Distinguishing characteristics, applications, and information resources. Ilar Journal 46: 258-268.

106. Riechmann L, Clark M, Waldmann H, Winter G (1988) Reshaping human antibodies for therapy. Nature 332: 323-327.

107. Queen C, Schneider WP, Selick HE, Payne PW, Landolfi NF, et al. (1989) A humanized antibody that binds to the interleukin 2 receptor. Proc Natl Acad Sci U S A 86: 10029-10033.

108. Hwang WY, Foote J (2005) Immunogenicity of engineered antibodies. Methods 36: 3-10.

109. Williams WB, Liao HX, Moody MA, Kepler TB, Alam SM, et al. (2015) HIV-1 VACCINES. Diversion of HIV-1 vaccine-induced immunity by gp41-microbiota cross-reactive antibodies. Science 349: aab1253. 